\title{
Article
}

\section{The optics of dispossession: urban precarity as political art}

\section{Uli Linke}

Professor of Anthropology, Department of Sociology and Anthropology, College of Liberal Arts, Rochester Institute of Technology, New York, USA; uhlgss@rit.edu

\section{Guest Editor: Andy Buchanan, Purdue University, USA}

Submission date: 10 January 2021; Acceptance date: 10 April 2021; Publication date: 1 December 2021

\section{How to cite}

Linke, U. 'The optics of dispossession: urban precarity as political art'. Architecture_MPS 20, 1 (2021): 4. DOI: https://doi.org/10.14324/111.444.amps.2021v20i1.004.

\section{Peer review}

This article has been peer-reviewed through the journal's standard double-blind peer review, where both the reviewers and authors are anonymised during review.

\section{Copyright}

2021, Uli Linke. This is an open-access article distributed under the terms of the Creative Commons Attribution Licence (CC BY) 4.0 https://creativecommons.org/licenses/by/4.0/, which permits unrestricted use, distribution and reproduction in any medium, provided the original author and source are credited • DOI: https://doi.org/10.14324/111.444.amps.2021v20i1.004.

\section{Open access}

Architecture_MPS is a peer-reviewed open-access journal.

\begin{abstract}
How are conditions of urban dispossession sustained and perpetuated by the way peoples on the margins of the world economy are imagined and brought to public visibility? With a focus on the works of European artists, this article explores the image-making projects whereby ghettos, shanty communities and favelas are represented as iconic lifeworlds of the poor. Competing representations of urban poverty are manufactured for public attention by aesthetic, symbolic and affective means, ranging from a romance of despair or humanitarian compassion to a nostalgic longing for premodern signs of a deprived but simpler life. In contrast to the racialised human form, which is central to iconographies of the North American Black ghetto, the shanty-town inhabitants and city builders of the Global South are typically rendered visually absent: a tropology of people's disempowerment and dispossession. Although often encoded by a critique of intensifying inequalities, the globalised traffic in urban poverty-art relies on an image-making process that is grounded in a detachment from social life. The representations of urban dispossession tend to produce a repertoire of free-floating emblems and signs that can be variously deployed, assembled, appropriated and
\end{abstract}




\begin{abstract}
discarded. Such visual templates are globally consumed as works of art that can alter urban imaginaries, encourage tourism and local economic development as much as neoliberal subjectification. After analysing a range of such artistic endeavours, this article concludes by focusing attention on how an image-maker's commitment to humanising optics of urban dispossession can transform non-representational art to become a practice of truth.
\end{abstract}

Keywords race; space; city; slum; ghetto; art; representation; optics; image

\title{
Framing the argument: an introduction
}

How are visual representations of inequality in cities of the Global South forged and produced for transnational publics? What are the implications of transforming urban architectural landscapes of dispossession into aesthetic objects? In analysing the works of visual artists, whose creative attention to the mega-slums in the Americas and Africa exposes the precarity of city life, my work traces the optics of placemaking at the urban margins. When do such architectural art forms become political, that is, serve as imaginative frames for unmasking urban inequities and human struggle? My discussion builds on a long history of political art and the city and expands on my previous investigations. In earlier projects, I explored how racial hegemonies are sustained and perpetuated by the ways in which urban spaces inhabited by peoples on the margins of the world economy are imagined, represented and brought to public visibility. ${ }^{1}$ Central to my inquiry was how iconic representations of 'slum life' are produced for a White consumer public. Propelled by fantasies of racial essence, primal bodies and exotic naturalism, the iconicities of 'shanty towns' and the 'Black ghetto' have been circulated as popular commodity forms throughout Europe's metropolitan centres. In analysing this process, I identified the optics of 'Africanism' (spaces of contested Black civility, premodern savagery, urban jungle) and 'tropicalism' (naturalised landscapes of colour and houses, childlike creativity and happy workers) as antithetical representational codes for how 'slums' as sites of urban dispossession are racially mapped and consumed. ${ }^{2}$

In this article, I follow a novel trajectory, turning my attention to specific projects in the Global South to uncover a multitude of practices whereby urban poverty, violence and dispossession in mega-slums have been visually transformed into aestheticised art forms, as intervention projects initiated by European architects and artists. As a visual anthropologist, my analysis is guided by uncovering the hidden meanings of altering the skin or surface of slum architecture and the implications of such aesthetic transformations for urban inequalities. In my previous research, I attempted to focus my analysis on the antithetical representational strategies for making visible the Black ghetto and the architectural landscape of the expansive urban slums of mega-cities in the Global South. While race was central in the image-culture of the ghetto, visual depictions of the tropicalised shanty settlements tended to erase racial markers. The photographed houses were rendered visually devoid of any signifiers of race. They often lacked identifying markers of locality, country and continent. Situated in a natural setting, the shanty homes and slum architecture seemed to have been deterritorialised and dehistoricised. Since the inhabitants were typically absent from the visual frame, the images were rendered globally portable. Let me briefly elaborate to make the focus of my essay more succinctly accessible to diverse disciplinary readers.

\section{The Black ghetto}

In the USA, the inner-city slum or urban ghetto stands as an ideogram of salient non-White others: disenfranchised 'poor people concentrated in derelict cores and inner suburbs'. ${ }^{3}$ Constructed as a carceral space, the ghetto emerges as a 'poverty warehouse' in urban centres. ${ }^{4}$ Confined to 'the racialised core of the US metropolis', following Loïc Wacquant, the ghetto has been envisioned as a template of violence and illegality, as a negative social space that breeds and reproduces criminality. ${ }^{5}$ Human beings, who find themselves entrapped within these spatial confines, as Achille Mbembe argued, are imagined as part of a 'multitude' of undesirable others, as signs of a dangerous, teeming humanity 
that needs to be contained. ${ }^{6}$ Framed by these cultural imaginaries, inner-city residents have been treated as societal surplus: valueless, useless and disposable. ${ }^{7}$ In the early twentieth century, when city neighbourhoods in the USA were racialised as Black and African American, according to Richard Sennett, the urban ghetto acquired its modern meanings: a carceral space inhabited by 'those who have been left behind', those destined to endure 'segregated lives' in 'zones of poverty' and 'common failure'. ${ }^{8}$ From its inception, the Black ghetto was conceived as a location for ethnoracial segregation, the designated space for 'urban outcasts'. ${ }^{9}$ Propelled into the present, the construct of the 'ghetto' fuses these two political moments of late capitalism: as a regime of warehousing poverty (by dehumanisation) and controlling surplus labour (by criminalisation).

Such depictions of the ghetto are founded on racial fantasies of threat. In the USA, as Stephen Steinberg observed, 'we speak euphemistically of "the urban jungle" [and] portray the inner city as a haven of pathology, disorder, and immorality', which comes close to 'declaring its inhabitants "uncivilized"'. ${ }^{10}$ The euphemism of the inner-city ghetto as a 'jungle' implies wilderness, a dangerous place, the habitat of untamed nature, 'where the wild things are':11 the primal, violent and sexually unrestrained. Popular representations of the ghetto, in turn, mobilise signs that confirm the negated humanity of inner-city residents: the figure of the Black other, which is a construct inflected by the racial logic of the White gaze and the controlling exercise of state power. ${ }^{12}$ Entrapped within this metaphorical field, as Allen Feldman noted, the Black male body has been marked by 'the stigma of animality', a 'bestial imagery' that simultaneously prescribes police responses of 'taming and caging'. ${ }^{13}$ By the second decade of the twenty-first century, such violent imaginaries were increasingly interlocked with public practices of hunting and killing. After 2016, in Trump's fortified America, racialised human beings - Black, Indigenous, Latinx - have inspired an intense apprehension, generating both fear and resentment, making them targets of street violence and state terror. Dispossessed of rights, they have been brutalised, silenced and murdered. ${ }^{14}$ The call to 'white power', as publicised and reified by Trump's social media ventriloquism, ${ }^{15}$ is a call to 'dark' love - not an enduring affection for the nation, but rather a summons to mobilise state violence against non-White citizens and immigrants. Among the dehumanising practices authorised by such rallying calls for a White America are acts of atrocity, including the execution of Black men in public view, in the street, captured on camera - killings committed by police officers in uniform. ${ }^{16}$ What are the implications of this turn to Whiteness for the American body politic and the Black ghetto?

The cultural production of such racial archetypes has been sustained by concrete semiotic frames. The urban jungle metaphor can be linked to an Africanisation of the ghetto. As I have previously argued, the discourse of Africa, as analysed by Achille Mbembe, ${ }^{17}$ operates as a template for the iconicity of the US inner-city ghetto. These very notions are encoded in signifiers of the ghetto-look, whereby the ascribed animalistic or pre-social disposition of the salient ghetto other is reified and recycled in the national imagination. The televised spectacle of hurricane Katrina's destructive force along the Gulf Coast in 2005 provides a pertinent example. In the wake of the storm, the Africanisation of US inner cities was rendered most visible when global audiences saw the total neglect of stranded poor Black people in New Orleans, with media reports of violence and looting wildly exaggerated, revealing the long-standing racial stereotypes of Black savagery. ${ }^{18}$ Fantasies of the lawless, Africanised city, renamed 'Little Somalia' by rescue workers, suggested the need to restore order by force and to liberate the urban 'enterprise zone' with military combat tactics from the 'insurgency' of Black resident-survivors. ${ }^{19}$ Similar notions of racial threat resurfaced during the 2008 US presidential campaign, when the candidacy of Hawaiian-born Barack Obama was contested by denying the plausibility of his American citizenship: as a Black man, he was cast as a Kenyan immigrant, thereby imagined as no more than a 'displaced African savage' and no less than a potential 'Black-Arab-Muslim terrorist'. ${ }^{20}$

These racialising machinations were documented by mainstream media in the same manner as the image-feeds from post-Katrina New Orleans. Reports of the inundated city, with its broken levees, ignited public anxieties about Black violence out of bounds, a savagery unleashed by the terrifying deluge that had flushed out the 'wild' from a forgotten urban habitat in the southern USA. As the city lay in ruins, venture capitalists began to organise sightseeing tours to the sites of destruction, accompanied by the sale of Katrina souvenirs for ghetto tourists. Thereby the dead zones of urban immiseration and the demodernised spaces of Blackness were not merely commoditised, as Kevin Gotham observed, but presented as 'a collage of fixed and static images that [were] marketed and interpreted for tourists'. ${ }^{21}$ Such forms of selling bits and pieces of the Africanised city seemed particularly effective when the appropriated styling elements were presumed to be derived from the voices of 
the 'ghetto' or self-produced by the dispossessed (music, body art, clothing). In these instances, the imagined ability to 'tap into reservoirs of cultural or historical practices of resistance'22 intensified the signifying capacity of purchased proxy objects, magnifying the sense of intimacy with rebellious Black cultural styles. Conceptions of the US inner-city ghetto as a negative space and its Africanised inhabitants as 'violent', 'uncivilised' and 'premodern' are thereby continuously recycled in tangible form. Images of the failed city and signs of the abject body are offered up for purchase to consumers as embattled identity accessories. In this process, whereby the cultural tropes of the Africanised ghetto are sold for profit, the politics of spatial segregation, unequal opportunity and systemic discrimination have receded from public visibility, subsumed by the horrifying media spectacles of acts of street violence against Black men committed by police.

\section{Engaging the optics of dispossession: the Global South}

How do these racialising machinations of the inner-city poor in North America compare to views of urban dispossession in the Global South? What types of fantasies are propagated by images of those informal settlements called 'shanty towns', 'favelas' or 'barrios'? While the portable signs of the Africanised Black ghetto are propelled by racial histories and assertions of a failed modernity, shanty cities are seen as part of a 'new world' order. ${ }^{23}$ In contrast to the racially homogenised lifeworld of the Black ghetto, shanty towns are typified as settlements with utterly diverse inhabitants: refugees, poor families, displaced farmers, labour migrants, returning combat veterans, unemployed workers and low-income professionals. ${ }^{24}$ Although this very diversity of the urban immigrant population is often experienced as threatening by nationalist regimes, local city elites and middle-class urbanites, who see flux, mobility and difference as signs of a destabilising national and global economic order, the translocal machination paints a different picture, offering an alternative world-building model. Shanty settlements have been envisioned as a new urban frontier situated on the edge of wilderness, where pioneer settlers transform uninhabitable spaces: unstable hillsides, rubbish mountains, chemical dumps. ${ }^{25}$ Shanty occupants are regarded as positive agents, as industrious workers, who produce value and transform environments while patiently enduring the repressive apparatus of state and municipal governments. In contrast to popular machinations of the Black ghetto, which spectacularise the abject body to reify race, place and difference, shanty towns are typified by pictorial representations of the built environment. Visual attention, I argued, shifts from the racialised ghetto body (Black skin) to signifiers of urban architecture. The tropicalised world of shanty towns, in opposition to the iconicity of the Black ghetto, unfolds under the signs of nature, art and beauty. The visual codes whereby shanty settlements or favelas enter into global commodity culture are centred on the products of labour: the homes and living spaces built by squatters. Representational images magnify architectural eccentricities in a naturalised urban landscape. Public spaces are shown devoid of people, history and culture. Signs of social life are missing. Nearly all traces of the inhabitants have been removed. Evidence of domestic activity, including scraps of building material or scatters of refuse, have been expunged from the visual field. In such visual representations, shanty houses are shown as edifices of architectural distinction and conjure attention with vibrant colours. Colour, art and architecture are combined as signs of a tropicalised landscape, in which the shanty houses, much like the figures in Gauguin's South Sea paintings, suggest vibrancy, a love of life and a surplus of creative energy. Importantly, the racial threat, so closely associated with the Black ghetto, has thereby been erased from the visual frame.

The desire to bring the 'colourful' alter-realities of urban life from other continents to Europe is puzzling. Why would White publics want to see shanty towns as iconic artworks of the urban poor? While the showing of favela architecture invites visual intimacy with the signposts of dispossession from other worlds, such exhibits also reify machinations of race and difference. When shown as beautified but de-fleshed architectural forms, as I have suggested, shanty artefacts sustain Europe's imperialist designs of tropicalised urban worlds. Whereas the Black ghetto emerges as an urban space defined by racial frames anchored to national histories of slavery and violence, images of the favela emphasise colour as a sign of diversity, thereby decentring public memories of human suffering and dispossession. By muting or rendering opaque human presence, the visual field can successfully diffuse and dissipate the threat of Blackness. By contrast, the US ghetto is a spatial monument to the nation's violent history of racial abjection linked to the colour of skin. As Caroline Randall Williams so eloquently articulated this insight amid the Black Lives Matter protests in her provocative exploration of race, identity and society: 
I have rape-colored skin. My light-brown-blackness is a living testament to the rules, the practices, and the causes of the Old South ...My body is a monument. My skin is a monument ... I am a black Southern woman, and of my immediate white male ancestors, all of them were rapists. My very existence is a relic of slavery ... Yes, I am proud of every one of my black ancestors who survived slavery ...I am proof. I am proof [of] the grievous exploitation of black lives. ${ }^{26}$

The iconic Black ghetto centrifugally compresses these meanings to exist as a carceral urban space. Apprehended through the visual template of Black skin, it is defined as a 'destitute and fearsome locality', as Elijah Anderson asserted, and 'white people typically avoid black space' for this reason. ${ }^{27}$ In contrast to the racial trope of Black skin, which has become integral to the construct of the US ghetto, the habitat of the barrio or favela emerges as an urban space framed by its architectural skin, dissociated from its residents and the colour of their bodies. Emptied of people, favela spaces can be reimagined through an architectural canvas, a deracialised surface, redesigned and remade by European image-makers as a colourful, eccentric and eye-catching urban terrain that appears to be safe and engaging for tourists or sightseeing voyeurs.

\section{Favela architecture in polychrome}

An examination of the visual appropriations of favela cityscapes yields instructive insights into the transformative process that unfolds when European image-makers attempt to 'improve' the communities and homes of the dispossessed in the urban Global South. What cultural imaginaries are at work in altering the architectural skins of the houses manufactured by world builders in faraway lands? The proclivity for such corrective intervention in the appearance of edge-city façades is evident in the Favela Painting project. ${ }^{28}$ Conceived by a Dutch firm, headquartered in Amsterdam, the undertaking sought to rebrand Brazilian cities with a colourful makeover. ${ }^{29}$ The artist-owners of this corporate enterprise, Jeroen Koolhaas and Dre Urhahn, asserted that their intercontinental painting project aimed to 'build bridges between community art, urban planning, and social design ...to contribute to an inclusive world' ${ }^{30}$ The idea took form after the Dutch team travelled to Rio de Janeiro in 2005 to complete work on an unrelated project: making 'a documentary film about hip hop music'. ${ }^{31}$ While engaged in this artistic undertaking, Koolhaas and Urhahn noticed 'the immense social divide between people living in the favelas and other parts of the city', and they subsequently conceived of a plan to 'paint an entire hillside favela'. ${ }^{32}$ As the artists elaborated: 'The project would give the favela population an opportunity to reshape their living environment with colourful art while improving the houses. Jobs would be created and the local economy stimulated'. ${ }^{33}$ By 2010, the Dutch team had completed their painting of housing clusters in several communities, including a district known as Praça Cantão, a neighbourhood in the Santa Marta favela of Rio de Janeiro (see Figure 1).

In these 'quick fix' touch-ups or visual makeovers, the painted cityscape stands as an auto-iconic art object, an incarnation of the Dutch project leaders' vision. The artists' goal was to 'cover the buildings in bright contrasting rays. The coloured lines run diagonally across the buildings, accentuating their organic positioning'. ${ }^{34}$ Exhibiting a uniform pattern of recurring colours and stripes, the favela houses seemed naturally entwined within a wholesome urban landscape - a simulacrum of vitality, exuding an aura of energy, vigour and a love of life. Displayed as edifices of architectural distinction, the favela buildings were not only beautified but staged as an urban dreamscape, in which the allure of colour functioned as 'the vehicle of spectacle' and as 'the language of consumption'. ${ }^{35}$ Not surprisingly, the Dutch project received worldwide media attention. The polychrome hues of the building façades pointed to a transformation of the slum communities, at least in visual ways. CNN commentators described the outcome of the favela project as a 'facelift', applauding the Dutch firm's efforts to rejuvenate and revitalise the district, and to 'turn the community into a living canvas'. ${ }^{36}$ In news interviews, the artists pointed to the positive media attention as a sign of their project's success, presumably confirmed by the fact that 'Praça Cantão had become one of Rio's official tourist attractions'. ${ }^{37}$ Neoliberalism, I argue, generates imperialist (postcolonial) optics of modernity. 
Figure 1. Favela painting, Santa Marta, Rio de Janeiro, Brazil (Source: Andrea Pistolesi/Getty Images).

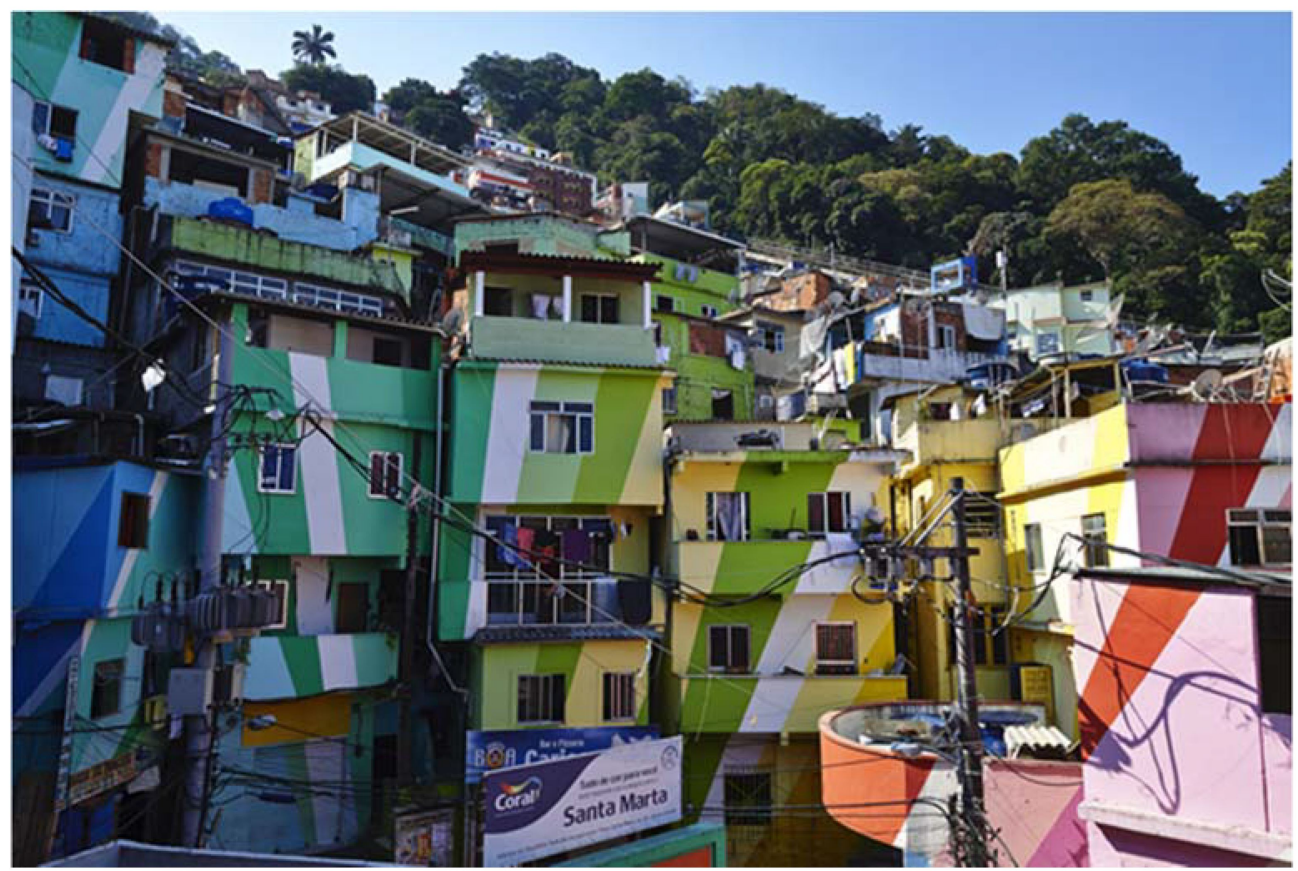

Yet visual surfaces can be deceiving. The Favela Painting project produces urban palimpsests, turning architectural façades into platforms for concealing traces of urban dispossession. Painting over the signs of urban trauma (bullet holes, cracks in infrastructure, the non-linear house designs) removes the exterior visibility of urban struggle. ${ }^{38}$ Poverty thereby is privatised, locked into the domestic interior, while the public signs of dispossession recede below the surface, pushed out of sight, covered by uniform coats of paint, applied in stripes, accentuating linear colour patterns to hide fractured difference. ${ }^{39}$ While the spectacle of coloured houses produces a Disney effect (a wholesome cityscape), the shanty community's struggle with racialised economic inequalities (Rio's White wealth) or political power (the intrusive presence of the state apparatus) is not apparent in the project's visual frame. In painting over poverty, the harsh realities of capitalism have been expunged from public sight and transformed favela architecture into aestheticised art objects: clean, colourful and uniquely spectacular. In an emancipatory move that simultaneously obscures the human faces of the inhabitants, the architectural images "let "art" speak for itself'. ${ }^{40}$ Such representational strategies toy with a problematic postulate: 'life is art' in the tropics, in the cities of the Global South. Aestheticised and modernised, the local conditions of urban dispossession have been overtly concealed. Tourist practices can thereby proceed undistracted by urban militarisation, criminalisation, economic deprivation, the abrogation of rights and the resultant ruination of local lifeworlds.

What were the effects of the Favela Painting project on the lives of people in the communities? In the words of the Dutch artists: 'The main objective was to create a huge piece of community art that served as a catalyst for the improvement of housing and neighbourhoods. By empowering and bringing colour and joy to these people, we hoped to ignite personal and societal change on all levels. ${ }^{41}$ Colour spectacles may promote slum tourism and generate a global industry for foreign travellers who desire to gaze at the poor; however, poverty and dispossession are not performative practices, staged for voyeuristic spectators. Slum tourism research suggests the failure of long-term economic viability. ${ }^{42}$ Furthermore, the Dutch development project was curiously detached from community life. The Favela Painting headquarters were located across the Atlantic in Amsterdam and contracted local labour in Rio de Janeiro to perform the menial work. While local men and women were hired by the Dutch project stakeholders as painters and workers, in temporary employment that was sometimes presented as opportune apprenticeships, local job prospects remained tied to the Dutch project: 'The Brazilian paint company Coral, a subsidiary of Holland's AkzoNobel, offered to help with raw materials and training for locals. ${ }^{43}$ Economic investment did not materialise beyond the parameters of the 'enormous murals 
painted on the walls of the favela' and the colour restoration of the artworks years later. ${ }^{44}$ Yet the initiative's global media impact inspired the Dutch firm to continue to create 'large-scale community art projects' across the world.

Although the initial goals of the Dutch favela painting project may have been well-intentioned, the artists proceeded with their plans of colour-coating select houses without sufficient knowledge of the local economic, social and environmental conditions. Their uncritical or perhaps naïve approach to favela realities is likewise evident in their unfamiliarity with Rio de Janeiro climate challenges and the corresponding selection of suitable paint materials. Analogue to the anticipated long-term economic development, the artwork itself failed to endure and has deteriorated. As articulated by the artists eight years after the completion of the project:

Time has taken its toll on the painting. In some parts, the paint has almost completely faded, [requiring] a more sustainable solution. We developed a new workflow, using pigmented lime stucco and tiles. Not only will the new exteriors of the houses last much longer, the homes themselves were improved beforehand. Defective walls were repaired and messy electricity lines were cleaned up. ${ }^{45}$

The artists' language betrays the persistence of a modernist vision and interventionist entitlement by drawing on a European sense of order, with a logic of lines, coherent surfaces and colour-saturated exteriors as tropes of 'the good life'.

\section{Modernising the fractured}

How can image-makers and urban artists enhance public awareness of edge-cities (slum, ghetto, favela, barrio) as sites of disempowerment or as terrains of exclusion and inequality? A critique of the relations of power that govern everyday life in shanty communities requires a complex representational approach. In order to make visible the collusion between global capitalism, racialising machinations and state (dis)interest, several artists have turned their attention to how the 'effects are materialized in the geography of the city'. ${ }^{46}$ In such works, however, favela architecture comes into view as a colossal construct whose logic is inaccessible or unintelligible to the European observer. Political artists, in turn, emerge as meaning-makers, providing insight on and attention to urban struggle. In this process, favela architecture is visually estranged: the urban images are modified and altered to inscribe a modernist coherence, a normative rational order. Techniques of estrangement and defamiliarisation provide a modular screen that translates the urban object into a comprehensible composite. ${ }^{47}$ New iconicities of edge-city communities are brought into existence to incite public curiosity by drawing attention to the grotesque or uncanny.

This representational strategy is evident in the works of the Spanish photographer and digital artist Dionisio González, who has become known in Europe for his startling depictions of favelas in Sao Paulo and Rio de Janeiro (see Figure 2). ${ }^{48}$ The artist's focus is on the 'geometric disarray' of these architectural forms. Working with photographic images that capture unique building designs, González creates art by redesigning those urban housing forms that he perceives to be 'unplanned', 'disorderly' and disturbingly 'chaotic'. According to a statement by his former Berlin agency, Fiedler Taubert Contemporary, 'the labyrinthine and improvised structures of the favelas are in a constant state of flux; they continually grow and change, completely untouched by the logical order of a planned city. González attempts to capture this flux in his photographic works' ${ }^{49}$

In addition to his camera work, González relies on computer-assisted imaging techniques to superpose modernist structures and geometric forms on his photographic objects, thereby fabricating a new architectural aesthetic. In an attempt to intervene in 'the architectural disarrangement of shanty towns in Sao Paulo, Brazil', the artist recombines 'the clean and modern with the grungy and scattered'. ${ }^{50}$ While each of the works emphasises different motifs, the artist pursues a modernist alteration of the shanty houses, which are reshaped by the visual insertion of objects, patterns and appendages to accentuate an orderly synchronicity of form. The result is a surreal urban landscape, in which the colours and exterior shapes of favela houses are blended and fused to create startling but impossible and non-functional designs. Here, as in the 'Favela Painting project', the political message remains with bringing attention to the lifeworlds of the urban poor through artistic estrangement. ${ }^{51}$ 
Figure 2. Nova Heliópolis II, São Paulo, Brazil (Source: Dionisio González).

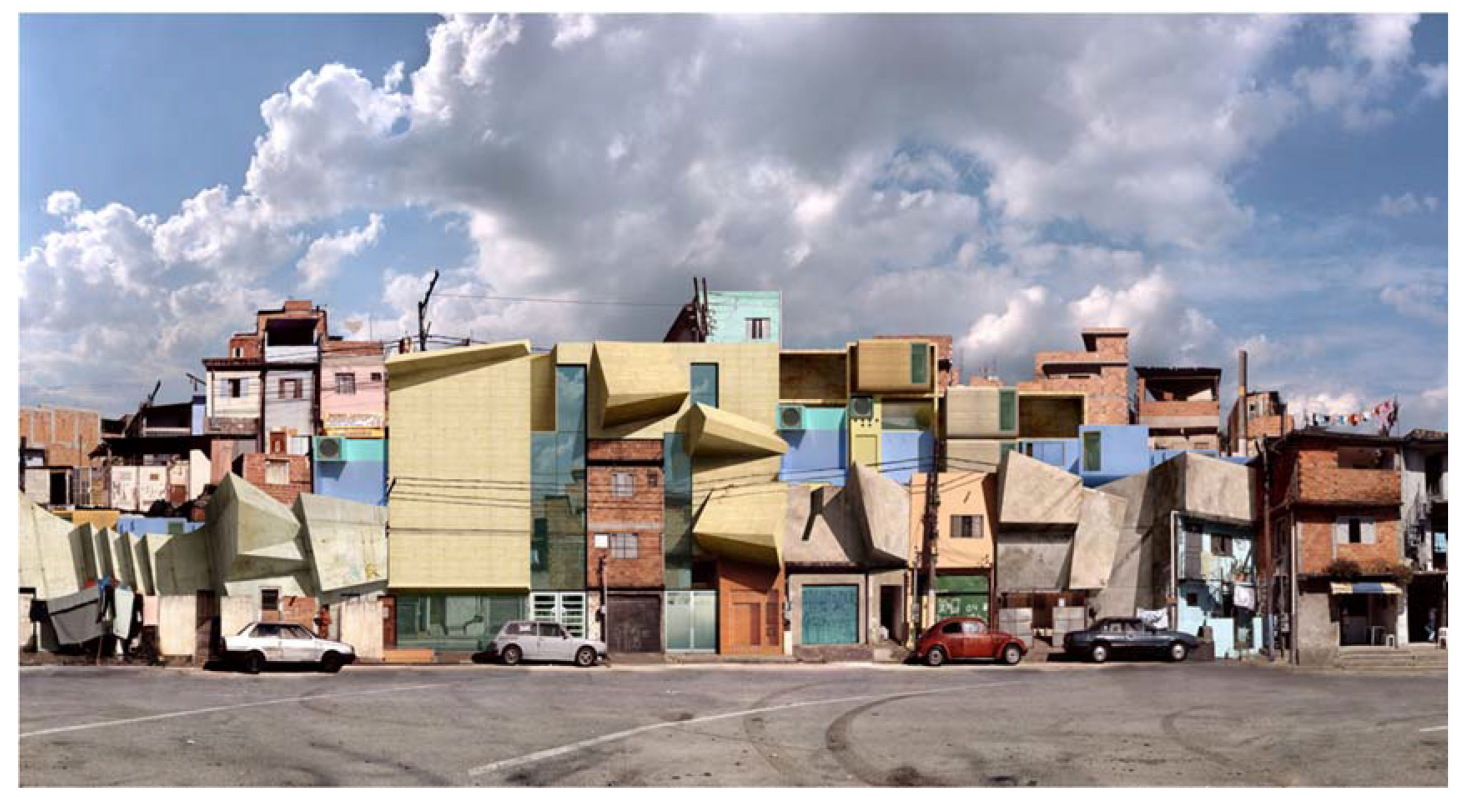

The artist's favela images are seemingly lifeless: the ground (streets, sidewalks) is swept clean; cars, tyre tracks, windows, illusive entryways and sometimes laundry hanging from a clothesline are the sole indexes and reference points for human presence. By focusing his attention on 'these massive, unregulated settlements', González not only attempts 'a partial intervention of these "chaotic spaces"' but 'proposes a radical restructuring' of shanty-town architecture by 'improving the precarious conditions of habitability'. ${ }^{52}$ Although these representational works acknowledge the agency of the city-building inhabitants, the product of their labour is perceived as deficient, requiring intervention. Techniques of estrangement have become an artistic tool for the visual erasure of poverty, as if seeing and looking at shanty towns must be facilitated by the transformation of social and architectural realities for a global consumer public. The manufactured images not only impose a modernist logic but also present sanitised visual realities - emptied of people and social worlds. Through these tactics of estrangement, shanty architecture is no longer envisioned as 'home', 'house' or 'dwelling' inhabited by actual people.

The artist's modernist critique of such informal urban settlements is apparent in images of ruinous landscapes, dead zones and bizarre architectural forms, which are exhibited as 'exquisite cadavers' (see Figure 3). ${ }^{53}$ The artist's depiction of urban immigrant communities as cities of the dead is striking. Seen through the lens of burial practices in Spain, and visualised through cemetery aesthetics, the motif of entombing corpses in wall crypts surfaces as a dominant cipher in these visual imaginings of the urban landscape. ${ }^{54}$ In contrast to the romance with poverty-porn promoted by the Favela Painting project, economic despair emerges as a master trope in Dionisio González's artworks. The ideological turn against favela architecture and its occupants has been imprinted in this transcultural modus of representation. ${ }^{55}$

\section{Slums as urban alter-realities}

Similar representational practices are evident in other art exhibits. The work of the French Algerian artist Kader Attia, for instance, includes an installation of an edge-city or slum formation titled Kasbah. ${ }^{56}$ Although designed as a reflection on urban poverty worldwide, the artist reimagines edge-city architecture by use of a single representational icon: a series of metal roofs, assembled from corrugated steel slabs, constructed at different heights and installed at different angles. Stretched across the ground of an entire exhibit hall, covering some 3,700 square feet, this expansive construct features a vast agglomeration of metallic-silver roof coverings, replete with satellite dishes, assorted tyres and other scrap materials. 
Figure 3. Exquisite Cadavers, São Paulo, Brazil (Source: Dionisio González).

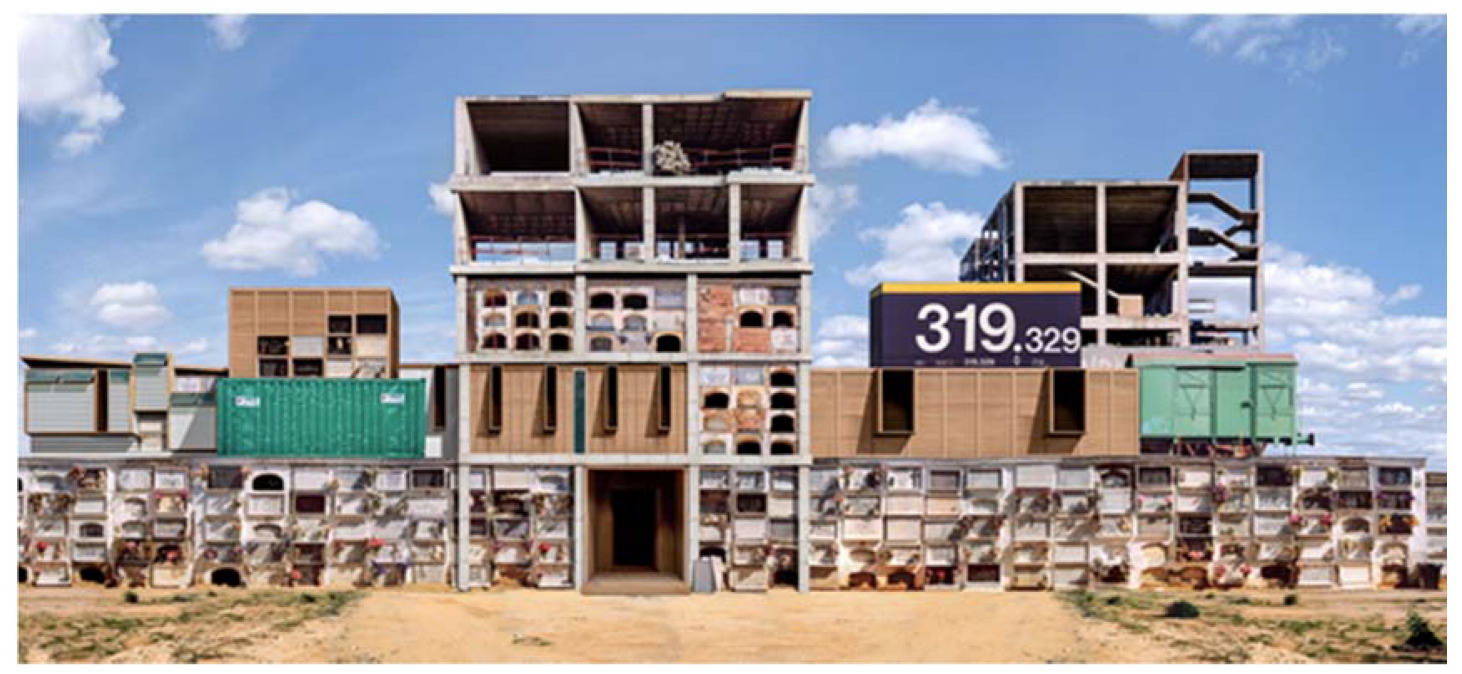

The exhibition consists of a bricolage of images and memories that originate from the artist's own life experiences. Kader Attia, a French national with Algerian family ties, grew up in the banlieues of Paris, in a north African immigrant community on the urban periphery, a site of poverty and discrimination. After studying art in Paris and Barcelona, Attia spent three years in the slums of Brazzaville and Kinshasa (Democratic Republic of Congo), an ethnographic practice that undoubtedly inspired his artistic visions and representational choices. Although the installation assembles translocal images of dispossession, Attia visualises his work in terms of a Kasbah, a North African medina or Islamic city. By using this architectural trope, the artist interprets slums as fortified, defensive constructs. In the exhibition, the primary signifiers of this motif enter the visual field as an expansive urban landscape of metal rooftops, variously arranged across a horizontal ground. The idea of a shanty community as a protective enclosure is implied, simulated by an artistic construct that invites visitors to look at and walk across the installation to re-enact the tactics of power - visually and physically (see Figure 4).

The socio-spatial formations of dispossession and disempowerment have been encoded into the art exhibit. Positioned on the ground, at the spectators' feet, the shanty rooftops come into view as isometric miniatures, creating a sense of spatial and social distance. The objects on display are apprehended from an aerial perspective. Exhibit visitors, like slum tourists, enact unequal relations of power in the practice of looking: by 'gazing at the poor' from a safe distance and an elevated position: the vantage points of privilege. ${ }^{57}$ In a further attempt to stage inequality in performative terms, visitors are invited to walk across the installation's metal components. According to the artist:

The difficulty of taking each cautious step over this uneven, variegated surface provokes a consideration of the successes and failures of the globalised economy and of the human ability to wrest a liveable existence from nothing. Thus, by walking tentatively over the work, across the metal roofs, visitors were not only to become part of the project but also implicitly part of the economic and power matrix that created these shanty towns. ${ }^{58}$

Kader Attia's work directs public attention to unequal power relations, striving to make seen acts of privilege through performative and participatory art, and to thereby expose our complicity in domination and exploitation. In the exhibit, the primary signifiers of urban dispossession appear as material icons: shanty architecture. In contrast to the centrality of the racialised human form that populates imaginaries of the US Black ghetto, the shanty inhabitants and city builders are rendered visually absent. But in Kader Attia's work, human absence is strategic. It signifies the lack of power and agency of those rendered unseen. In the installation, the historical contexts of urban inequalities are discursively constructed rather than visually presented. In an act of 'topographical amnesia', following Paul Verilio, ${ }^{59}$ signs of poverty have become representational signs of edge-cities and their dematerialised inhabitants, which circulate as globally mobile signifiers of dispossession that are consumed as performative art works. By relying on 
a universalising code of art, urban inequalities are transformed into aestheticised commodity-objects, which are displayed in art exhibits. This process relies on a problematic reification of the optics of dispossession, as I have suggested throughout this essay.

Figure 4. Kasbah, installation by Kader Attia, Sydney Art Biennale 2010, Australia (Source: Alison Young).

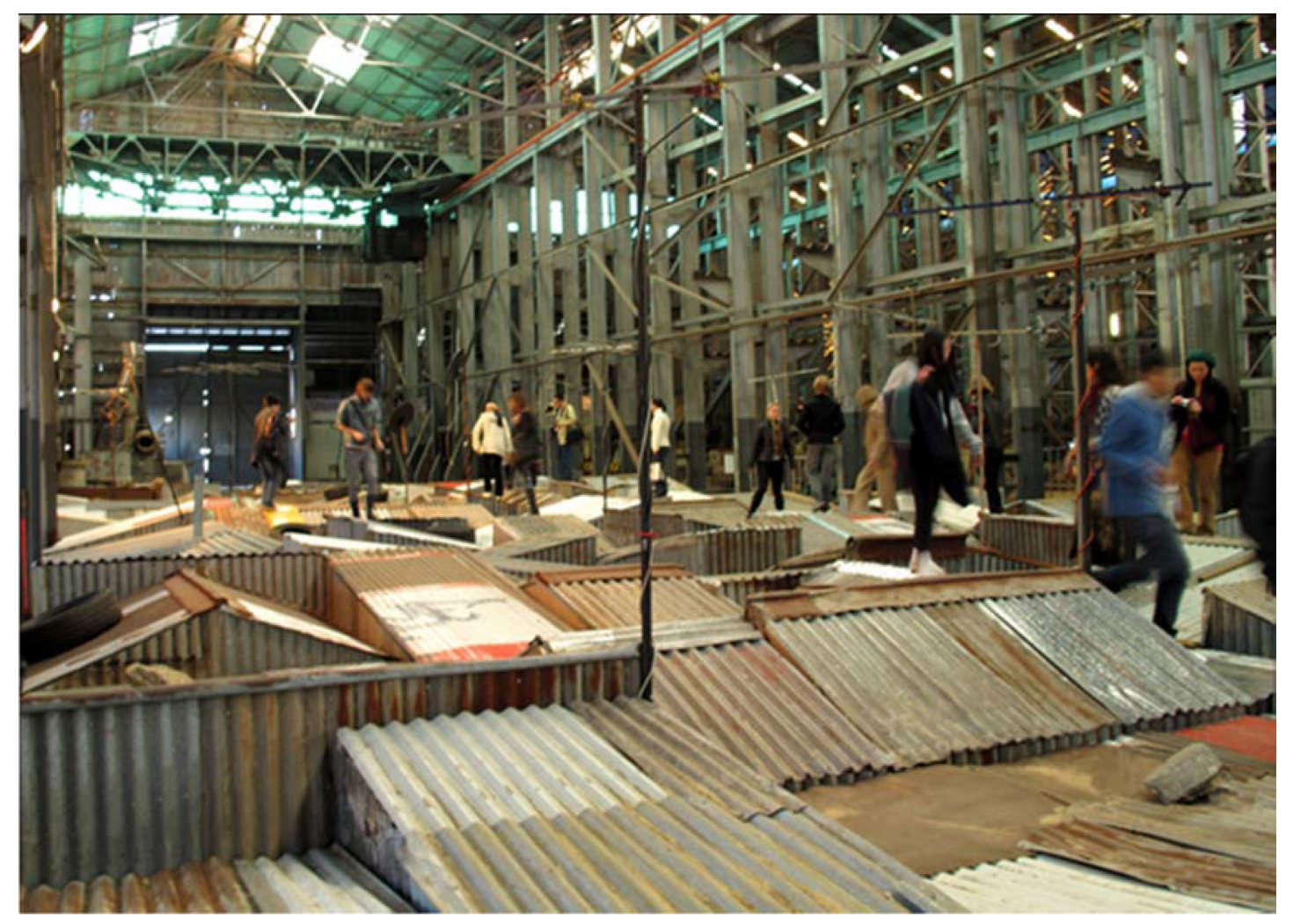

\section{Art as a practice of truth: a tentative conclusion}

Visual representations of urban dispossession, when conceived as works of art, tend to focus public attention on favela architecture. Yet in the attempt to expose principles of disempowerment or systemic oppression, art can often magnify facets of inequality through estrangement or distortion. In all cases, artistic tropes draw on the artist's aesthetic imagination to fashion hyperrealities of favela cities, thereby transmuting the artist's cultural fantasies into representational artefacts with communicative power. In these formative creative acts, however, the iconic architecture of favela life as a master-trope of metropolitanism in the Global South, as suggested by Pushpa Arabindoo, is 'no longer about reducing poverty but about rendering the poor invisible'.60 The erasure of slum builders from the frame of representation is, I would argue, not merely a deracialising tactic. The focus on architectural landscapes emptied of people points to a more critical issue in the modality of Western representation. The manner in which film, photography, digital media and art bring to visibility Native peoples for global audiences has been contested by visual anthropologists as a problematic trace of colonialism and form of 'imperial debris', a notion sedimented in disciplinary memory by adopting the lens of postcolonial critics. ${ }^{61}$ In pictorial media, human absence is itself a form of representation - yet not merely an erasure of human beings or of racial signifiers. It is at once an abrogation of people's voice and agency, a denial of the self-representational power of the dispossessed that persists in some of the works of European favela artists. Such an imperialist perception has been challenged. There can exist an alternative, more humanising, aesthetic of dispossession, which follows a different trajectory and routes visual choices towards a liberative politics. 
The work of the French photographer JR, a street artist from Paris, exemplifies this radically distinctive approach. ${ }^{62}$ As a visual artist, JR has been committed to making those who have money, power and privilege see what has been hidden or ignored: to give voice to those who suffer in silence, hidden from public view. His artwork does not intend to speak 'for' or 'about' the dispossessed. Rather, his visual productions attempt to provide a medium through which those on the margins of society can find their own voices and can narrate themselves through visual means, such as photographs, digital images, film, video story-telling and dance performances, as modes of empowerment and agency. JR aims to make others take notice and pay attention to bring about change. Perhaps JR's photographic and video artworks are best described as a practice of truth.

He has a knack for making the invisible - people, usually, the poor, the marginalized, the forgotten - visible. It's all about trying to get people to take notice of the people we spend most of our lives failing to see, or maybe, more accurately, trying to avoid seeing. JR's work has been to find a strange angle or a previously hidden corner and bring them to us. He shows us them at massive scale, or across landscapes, or just in some new or surprising or beautiful way we weren't expecting. ${ }^{63}$

JR exhibits his work globally, on a worldwide stage. His visual media choices and his exhibition practices enable him to democratise art. As a street artist, he mounts his photographs in public spaces, where they can be seen by all - fleeting images, monumentally enlarged, covering entire buildings, bridges, sidewalks, trains, walls and mountain slopes, so that people cannot avoid seeing or looking while pursuing the tasks of everyday life.

How did this approach by the French artist come about? JR grew up in Paris. Like Kader Attia, he came of age in the urban slums or banlieues on the outskirts of this global city. His grandmother lived in Istanbul. Yet in France, he is neither identified as Turkish nor European. He is branded as 'half Arab' or 'African', since his mother was a Tunisian immigrant. 'He grew up on the wrong side of the Boulevard Péripherique, the ring-road that separates the bourgeois quartiers of central Paris from the places where it houses its large immigrant population: in huge concrete cités or public housing projects'. ${ }^{64} \mathrm{JR}$ began his career as a street artist in 2001, as a fifteen-year-old student in high school, when he started to use spray paint to draw attention to local issues. ${ }^{65}$ Several years later, he acquired a small camera and began his work as a graffiti photo artist, taking images of his neighbourhood, pasting them on buildings with glue, framing them with spray paint and thereby creating street galleries throughout Paris. In 2004, with his friend Ladj Ly, he created Clichés de Ghetto, a public photography exhibition, central to which were enlarged close-up snapshots of young people from the banlieues, images of everyday activities and faces. ${ }^{66}$ Less than a year later, during the 2005 Paris ghetto uprisings, JR returned to the neighbourhood, armed with a camera, and began another project. 'When Paris burned, the media coverage of the riots was a huge part of the story'. ${ }^{67}$ Under the onslaught of racialising tropes, equivalent to representations of the iconic Black ghetto, and being filmed from a distance, with telescopic lenses, young people trapped in the housing projects felt that they were 'being observed like animals'. ${ }^{68}$ Seen from afar, their Blackness was defined as a threat, and 'it looked like they were an army that was about to invade' the White spaces of Paris. ${ }^{69} \mathrm{JR}$ used his $28 \mathrm{~mm}$ camera to take close-up pictures of their faces, photographing the young adults' performative commentary on 'their own televised caricature' by the French media. ${ }^{70} \mathrm{He}$ then pasted the enlarged, super-sized images throughout Paris and 'captioned the photos with their names, age, and building numbers'. ${ }^{71}$ In this project, later titled '28MM: Portrait of a Generation', ${ }^{72}$ the aim was to humanise the teenagers, 'making their faces seen, making their voices heard', and to thereby curb White French fear of the Black terrain.

Grounded by these commitments, JR has remained a street artist who deploys documentary photography to realise his vision of the practice of truth: humanising, publicising and democratising local demands for rights, justice and equality by visually magnifying urban conditions of dispossession. In these endeavours, human faces are always central. His art projects are expansive and global: 'JR's canvases are now tower blocks, whole buildings, entire streets. His scale is epic, monumental ... He works with a large team of people across two continents, collaborates constantly, and communicates via Instagram, Twitter, Snapchat and the walls of dozens of cities around the world - relentlessly'. ${ }^{73}$ In a visual commentary on arbitrary national distinction, 'he turned the dividing wall between Israel and Palestine into a gallery of faces' ${ }^{74}$ He transformed cities and ghettos in African post-civil-war conflict zones with the eyes and faces of women who wanted to give voice to their suffering, while confined 
by poverty and violence. ${ }^{75}$ In Women are Heroes, JR visually captured the moments of pain that the women wanted to communicate and be seen by others. ${ }^{76}$ When he returned to France, he learned about a massacre of three young men committed by the Brazilian army in one of Rio de Janeiro's shanty communities, the Morro da Providência favela, an inner-city Black ghetto. This location in urban Brazil became the artist's next designation for the expansive Women are Heroes project. In summer 2008, he transformed an entire favela hillside with black-and-white photographs of women's eyes and faces (see Figure 5). In an interview with Raffi Khatchadourian, a reporter for The New Yorker, JR described the unfolding of events and his rapport with residents that enabled him to complete his public art exhibition in the favela. According to Khatchadourian:

Figure 5. Women are Heroes, installation by JR, Rio de Janeiro, Brazil, 2008 (Source: Vanderlei Almeida/Getty Images).

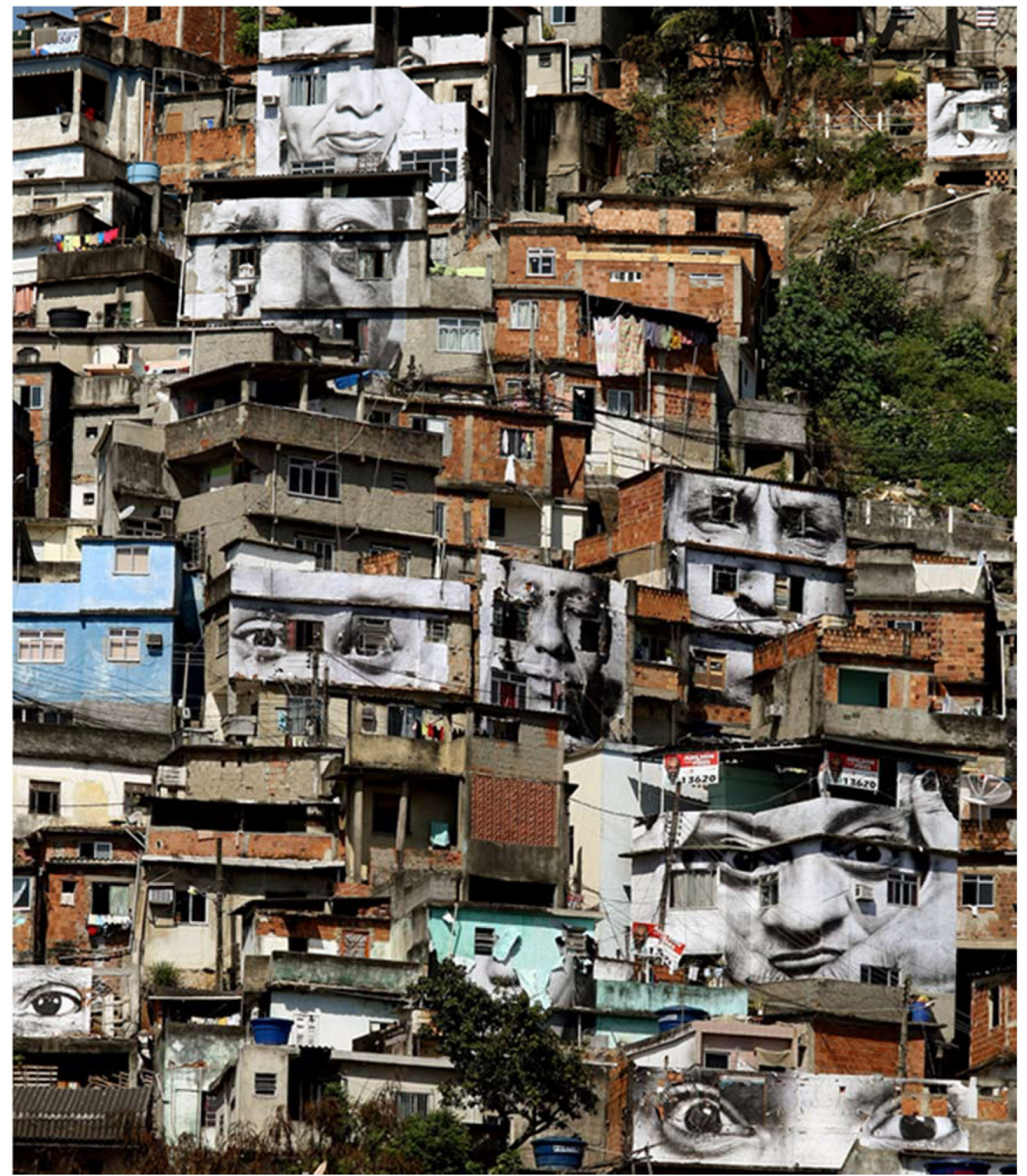


When JR heard of the killings in Brazil, he flew to Rio, walked up to the favela and introduced himself to the first person he saw. For a month, he visited every day, meeting with local drug lords, ducking under shoot-outs and earning the trust of the residents. Working just inches from his subjects' faces, he took photographs of women - a number of them related to the men who had been killed - and he enlisted locals to post the images on buildings overlooking the city. Their participation, he believed, was central to the piece - not a means but an end. 'That favela is in the center of town, but when you look at a map ... it is not there,' he told me. 'So the people were saying, "Hey, we are there, we are right there in front of you, and you pretend that we don't exist". It was like, "O.K., my house is ...not the best one, but we are not missing food. We are missing dignity, existence - people think that we are living like animals, and that's what we want to change".' When the media began investigating the pastings, JR vanished, forcing journalists to talk to the favela's inhabitants. 'More and more, people are conscious of how the media portray them', he told me. 'They want to control their image'. ${ }^{77}$

The visual effect of this monumental exhibition was stunning: framed in extreme close-up, 'the images of eyes, unblinking, and the size of buildings, ...pasted on shanties made from brick and concrete' ${ }^{78}$ As the gigantic eyes of the women looked down at the city of Rio, the city-sized artwork pushed the gendered dimensions of favela life into the foreground. In turn, the French photographer-graffiti artist drew worldwide media attention to local urban histories, pushing the women's visual and narrative voices of their trauma into the public contact zones of power. ${ }^{79}$ According to JR: 'They all wanted to share their story, so that their story travelled'. ${ }^{80}$ Whether in the slums of Kibera or the Brazilian favela, he promised the women to take their stories and images around the world - for all to see and to thereby promote change. He subsequently proceeded to display his photographic prints of women's eyes, faces and bodies in Europe's urban spaces (see Figure 6). As JR put it: 'It's important to have that visibility. If you are not seen, you are invisible, and people don't know that your problems exist'. 81

Figure 6. Women are Heroes, installation by JR, Paris, France, 2009 (Source: Pascal Berger).

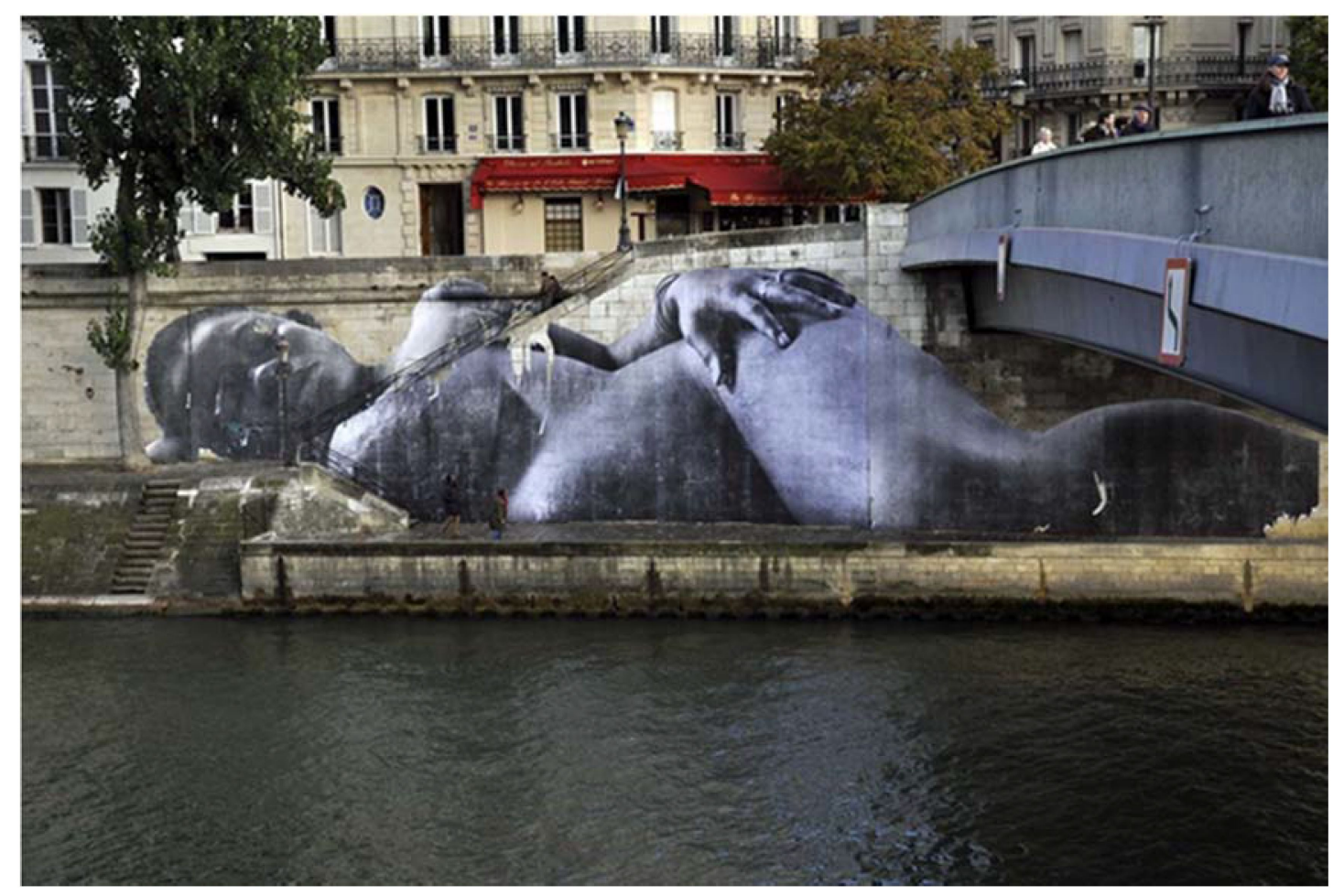

In 2009, JR and his team mounted a huge exhibition in Paris. As part of his Women are Heroes series, women's images from faraway ghettos, slums and favelas became 'space invaders', spilling into the white 
terrain. ${ }^{82}$ The shock effect was perhaps most noticeable when the gigantic image of a naked young woman, a pregnant Liberian refugee about to give birth, suddenly appeared on the Seine embankment in the predominantly White bourgeois community of Ile Saint-Louis. White Parisians had mixed responses to this public exhibition in their city. French art critics noted that the project 'lacked the quality of social connectedness that marks JR's best work'. ${ }^{83}$ Produced from the vantage point of White privilege, this criticism was, however, not wholly apposite. Previous iterations of the Women are Heroes project in Brazil or Liberia rendered the artist's passion for human rights advocacy self-evident by adhering to a form of ethnographic case-by-case engagement, that is, a localised photographic activism that was confined to publicising women's voices within and for distinct favelas or ghetto communities. Although the Parisian street art galleries did not include images of the city's immigrant poor or dispossessed, and thereby seemed to mute the voices of banlieue inhabitants, the Paris exhibition instead attempted to transport the collective plight of women from the world community to the metropolis. In this global city, I argue, the transnational visual gallery of women in despair, women from Africa, Asia and South America, precisely matched JR's focus on the globalisation of dispossession and the deterritorialised realities of struggle, a human rights concern brought to public visibility in the urban centre of a world power, the capital of a nation that formerly ruled an expansive colonial empire.

Guided by the principles of a graffiti artist, JR continues to push his humanising gaze towards a global stage, turning attention to local matters whereby his photographic art offers people a forum for publicising their voices, using various media for self-expression: video archives, choreography, dance, testimony and photography. His commitment to the dispossessed is absolute: he does not accept sponsorship from any person, agency or institution. Remaining a dedicated street artist, often working under cover of darkness, his humanistic photography disseminates people's voices and images all over the world, across all continents and cities, as his art promotes the practice of truth.

\section{Notes}

${ }^{1}$ See Linke, 'Mobile imaginaries'; and Linke, 'ICONi@Cities'.

'Linke, 'Racializing cities'.

${ }^{3}$ Davis, Planet of Slums, 31.

${ }^{4}$ Mendieta, 'Penalized spaces', 384-90.

${ }^{5}$ Wacquant, Urban Outcasts, 2.

${ }^{6}$ Mbembe, Critique of Black Reason, 11.

${ }^{7}$ Giroux, 'Violence', 305-9.

${ }^{8}$ Sennett, Flesh and Stone, 368.

${ }^{9}$ Wacquant, Urban Outcasts.

${ }^{10}$ Steinberg, 'The myth of concentrated poverty', 217.

${ }^{11}$ Mexal, 'Consuming cities', 238; and Mexal, 'The roots of "wilding"'.

${ }^{12}$ Wacquant, Urban Outcasts.

${ }^{13}$ Feldman, 'On cultural anesthesia', 409.

${ }^{14}$ See Hannah-Jones, 'Taking freedom'; Peeples, 'What the data say'; and Washington Post Database, 'Police shootings'.

${ }^{15}$ Wootson, '“White power" video'.

${ }^{16}$ Glaude, Begin Again.

${ }^{17}$ Mbembe, On the Postcolony, 1-3.

${ }^{18}$ Giroux, 'Violence'.

${ }^{19}$ Lipsitz, 'Learning from New Orleans', 454.

${ }^{20}$ Linke, 'Fortress Europe', 100-20.

${ }^{21}$ Gotham, '(Re)branding the big easy', 838.

${ }^{22}$ Rao, 'Slum as theory', 675.

${ }^{23}$ Neuwirth, Shadow Cities; and Algoed, 'The future of cities'.

${ }^{24}$ Perlman, Favela.

${ }^{25}$ Davis, Planet of Slums, 121.

${ }^{26}$ Williams, 'You want a Confederate monument'.

${ }^{27}$ Anderson, 'The White space', 10.

${ }^{28}$ Koolhaas and Urhahn, 'The Favela Painting Project'. 
${ }^{29}$ Koolhaas and Urhahn, 'The Favela Painting Project'.

${ }^{30}$ Koolhaas and Urhahn, 'Favela Painting: Community Art for Social Change'.

${ }^{31}$ Koolhaas and Urhahn, 'The Favela Painting Project'.

${ }^{32}$ Koolhaas and Urhahn, 'The Favela Painting Project'.

${ }^{33}$ Koolhaas and Urhahn, 'The Favela Painting Project'.

${ }^{34}$ Koolhaas and Urhahn, 'Praça Cantão, Rio de Janeiro 2010'.

${ }^{35}$ Lutz and Collins, Reading the National Geographic, 94.

${ }^{36}$ Darlington, 'Rio slum transformed'.

${ }^{37}$ Koolhaas and Urhahn, 'The Favela Painting Project'.

${ }^{38}$ See the images provided by Koolhaas and Urhahn, 'Praça Cantão, Rio de Janeiro 2010'.

${ }^{39}$ See the photo images by Koolhaas and Urhahn, 'Santa Helena project: Rio de Janeiro 2017-2018'.

${ }^{40}$ Kirshenblatt-Gimblett, Destination Culture, 245.

${ }^{41}$ Koolhaas and Urhahn, 'Praça Cantão, Rio de Janeiro 2010'.

${ }^{42}$ See Rolfes, 'Poverty tourism'; Freire-Medeiros, Touring Poverty; and Linke, 'Racializing cities'.

${ }^{43}$ Darlington, 'Rio slum transformed'.

${ }^{44}$ Rahman, 'The impact of Favela painting'; also Koolhaas and Urhahn, 'Santa Helena Project'.

${ }^{45}$ Koolhaas and Urhahn, 'Santa Helena Project'.

${ }^{46}$ Wacquant, Urban Outcasts, 2.

${ }^{47}$ See Kirshenblatt-Gimblett, Destination Culture, 203, 235.

${ }^{48}$ See website by Dionisio González, http://www. dionisiogonzalez.es/Cartografias.html, Image 21, Nova Heliopolis II. Reproduced with permission of the artist.

${ }^{49}$ See press release by Fiedler Taubert, 'Dionisio González: An assembled city'. (The gallery is now called Taubert Contemporary but the original website no longer exists.) Also see Gonzalez's website, Image 22, Nova Heliopolis III.

${ }^{50}$ Spear, 'Dionisio Gonzalez Photography'. (This blog no longer exists.)

${ }^{51}$ See González's website, Image 2, Paulistana Ajuntada.

${ }^{52}$ See Galería Max Estrella, 'Dionisio González'. The exposition of digital photographs by Dionisio González, titled 'Cartografías para a remoçao', was displayed by Galeria Max Estrella, 25 January to 3 March 2007, but is no longer available on the website. The text is from an excerpt of the artist's gallery exhibition announcement.

${ }^{53}$ Artwork from Serie Cadáveres Exquisitos (encriptaciones); see online exhibit of the works of artist Dionisio González by Taubert Contemporary: 'Favela: Encriptaciones, 2004'. The artwork for Figure 3, as shown here, was provided by and reproduced with the permission of Dionisio González, 14 January 2021. ${ }^{54}$ In Spain, such mausoleum crypt walls are common in cemetery burial grounds of Cartagena, Andalusia and Catalonia, where the dead are entombed in walls.

${ }^{55}$ See Appadurai, 'Sovereignty without territoriality', 337-49.

${ }^{56}$ Photo copyright Designboom; see Chung, 'Kader Attia'.

${ }^{57}$ Freire-Medeiros, Touring Poverty, 100, 128.

${ }^{58}$ Chung, 'Kader Attia'.

${ }^{59}$ Verilio, 'Topographical amnesia'.

${ }^{60}$ Arabindoo, 'Rhetoric of the "slum"', 341.

${ }^{61}$ See Stoler, 'Imperial debris', who coined the analytic term; for the related discussion on representation, see Ruby, 'Speaking for, speaking about'; Shohat, 'Struggle over representation'; and Spivak, The Post-Colonial Critic.

${ }^{62}$ For a chronological listing of all of JR's projects, see JR, Can Art Change the World? And the website titled JR-ART.NET on which all projects, videos and films are archived with commentaries on the making and execution of each artwork in a section titled 'Chronicles'.

${ }^{63} \mathrm{Cadwalladr}$, 'JR: "I realized i was giving people a voice"'.

${ }^{64}$ Cadwalladr, 'JR'.

65JR, 'Beginnings 2001-2004'.

$66 \mathrm{JR}$ and Ly, 'Clichés de ghetto'.

${ }^{67}$ Cadwalladr, 'JR'.

${ }^{68} \mathrm{JR}$, 'Chronicles: Portrait of a generation'.

${ }^{69} \mathrm{Cadwalladr}$, 'JR'.

${ }^{70} \mathrm{JR}$ and Ly, '28MM - Portrait of a generation'.

${ }^{71} \mathrm{JR}$, 'Chronicles: Portrait of a generation'; see also Cadwalladr, 'JR'. 
72JR and Ly, '28MM - Portrait of a generation'.

${ }^{73} \mathrm{Cadwalladr}$, 'JR'.

${ }^{74}$ Cadwalladr, 'JR'; JR, 'Face2Face'; and 'Chronicles: Face2Face'.

${ }^{75} \mathrm{JR}$, 'Women are Heroes - Africa'; and 'Women are Heroes - Kenya, Kibera'.

76JR, 'Women are Heroes'; Redmond-Tiedrez, 'Women are Heroes by JR'; Brooks, 'All around the world'; Popova, 'Women are Heroes'.

${ }^{77}$ Khatchadourian, 'In the picture'.

${ }^{78}$ Khatchadourian, 'In the picture'.

${ }^{79}$ JR au JT FR3, 'Favela Morro da Providencia 2009 Reportage';

${ }^{80} \mathrm{JR}$, 'Women are Heroes - Africa; 'Women are Heroes - Kenya, Kibera'; and 'Women are Heroes'.

${ }^{81}$ Cadwalladr, 'JR'.

$82 \mathrm{JR}$, 'Women are Heroes - Exhibition in Paris 2009'.

${ }^{83}$ Khatchadourian, 'In the picture'. In feminist transnational race theory, the figure of the bare breasted or naked Black woman in twentieth-century visual media triggered similar controversies when this motif of the naturalised Black female body was critiqued as a manifestation of a colonial fantasy that visually depicted unclothed Natives through a primitivist, racialist, and dehumanizing lens: see Lutz and Collins, Reading the National Geographic, 103-7.

\section{Declarations and conflict of interests}

The author declares no conflicts of interest with this work.

\section{References}

Algoed, Line. 'The future of cities lies in the slums'. The Academy of Urbanism, 12 January 2015. Accessed 28 June 2021. https://www.academyofurbanism.org.uk/the-future-of-cities-lies-in-the-slums/.

Anderson, Elijah. 'The White space'. Sociology of Race and Ethnicity 1, no. 1 (2015): 10-21. [CrossRef]

Appadurai, Arjun. 'Sovereignty without territoriality'. In The Anthropology of Place and Space, edited by Setha M. Low and Lawrence D. Zúñiga, 337-49. Oxford: Blackwell, 2003.

Arabindoo, Pushpa. 'Rhetoric of the "slum"': rethinking urban poverty'. City 15, no. 6 (2011): 636-46. [CrossRef]

Brooks, Katherine. 'All around the world, a street artist proves 'Women are Heroes". Huffington Post, 14 July 2014. Accessed 28 June 2021. https://www.huffpost.com/entry/jr-women-are-heroes_n_ 5579086.

Cadwalladr, Carole. 'JR: "I realised i was giving people a voice"'. Guardian, 11 October 2015. Accessed 28 June 2021. https://www.theguardian.com/artanddesign/2015/oct/11/artist-jr-i-realised-i-wasgiving-people-a-voice-les-bosquets-french-banksy.

Chung, Fiona. 'Kader Attia: Kasbah installation'. Designboom, 23 May 2010. Accessed 28 June 2021. http://www.designboom.com/weblog/cat/10/view/10286/kader-attia-kasbah-installation.html.

Darlington, Shasta. 'Rio slum transformed into canvas bursting with color'. CNN, 17 November 2010. Accessed 28 June 2021. http://www.cnn.com/2010/WORLD/americas/11/17/brazil.beautiful.favela/ index.html.

Davis, Mike. Planet of Slums. London: Verso, 2017.

Feldman, Allen. 'On cultural anesthesia: From Rodney King to Desert Storm'. American Ethnologist 21, no. 2 (1994): 404-18. [CrossRef]

Fiedler, Taubert. 'Dionisio González: An assembled city'. Galerie Fiedler Taubert, 3 April 2006. Accessed 28 June 2021. http://fiedler.null2.net/index.php?id=329presse=1.

Freire-Medeiros, Bianca. Touring Poverty. London: Routledge, 2013.

Galería Max, Estrella. 'Dionisio González: Cartografías para a remoçao', 25 January 2007. Accessed 28 June 2021. http://www.maxestrella.com/exhibitions_2006\%20-\%202007.html.

Giroux, Henry A. 'Violence, Katrina and the biopolitics of disposability'. Theory, Culture and Society 24, nos. 7-8 (2007): 305-9. [CrossRef]

Glaude, Eddie S., Jr. Begin Again: James Baldwin's America and its urgent lessons for our own. New York: Random House, 2020.

Gotham, Kevin F. '(Re)branding the big easy: Tourism rebuilding in post-Katrina New Orleans'. Urban Affairs Review 42, no. 6 (2007): 823-50. [CrossRef] 
Hannah-Jones, Nikole. 'Taking freedom: Yes, Black America fears the police. Here's why'. Pacific Standard, 8 May 2018. Accessed 28 June 2021. https://psmag.com/social-justice/why-blackamerica-fears-the-police.

JR. 'Beginnings: Expos2Rue / Sidewalk Gallery (2001-2004)'. JR-ART.NET. Accessed 17 December 2020. Video, 1:56. http://www.jr-art.net/videos/beginnings.

JR. Can Art Change the World? Revised and expanded edition. New York: Phaidon, 2019.

JR. 'Chronicles: Face2Face'. JR-ART.NET. Accessed 2 January 2021. Video, 6:47. http://www.jr-art.net/ videos/jr-chronicles---face-2-face1.

JR. 'Chronicles: Portrait of a generation'. JR-ART.NET. Accessed 1 January 2021. Video, 1:36. http://www. jr-art.net/videos/jr-chronicles---portrait-of-a-generation1.

JR. 'Face2Face'. JR-ART.NET. Accessed 2 January 2021. Video, 5:30. http://www.jr-art.net/videos/ face2face-project-2007-vostfr.

JR. 'Favela Morro da Providencia 2009 reportage'. JR-ART.NET. Accessed 15 December 2020. Video, 3:04. https://vimeo.com/15688534.

JR. 'Women are Heroes - Brazil'. JR-ART.NET. Accessed 19 December 2020. Video, 9:11. http://www.jrart.net/videos/women-are-heroes---9minutes---vost-en.

JR. 'Women are Heroes - Africa'. Vimeo. Accessed 1 December 2020. Video, 6:35. https://vimeo.com/ 84770222.

JR. 'Women are Heroes - Kenya, Kibera'. JR-ART.NET. Accessed 5 December 2020. Video, 3:27 https:// vimeo.com/410939446. http://www.jr-art.net/videos/women-are-heroes---kenya-kibera---extract--2010--.

JR. 'Women are Heroes - Exhibition in Paris 2009'. JR-ART.NET. Accessed 16 December 2020. Video, 8:27. http://www.jr-art.net/videos/women-are-heroes---exhibition---paris---vost-en.

JR, and Ladj Ly. '28MM - Portrait of a generation'. JR-ART.NET. Accessed 28 December 2020. Video, 5:22. Accessed 28 June 2021. http://www.jr-art.net/videos/28mm-portrait-dune-generation---vost-en.

JR, and Ladj Ly. 'Clichés de ghetto: Clichy-Montfermeil'. JR-ART.NET. Accessed 21 December 2020. Video, 1:59. http://www.jr-art.net/videos/cliches-de-ghetto.

Khatchadourian, Raffi. 'In the picture: An artist's global experiment to help people be seen'. New Yorker, 21 November 2011. Accessed 28 June 2021. https://www.newyorker.com/magazine/2011/11/28/inthe-picture-raffi-khatchadourian.

Kirshenblatt-Gimblett, Barbara. Destination Culture. Berkeley: University of California Press, 1998.

Koolhaas, Jeroen, and Dre Urhahn. 'The Favela Painting Project 2005-2016, Rio de Janeiro (Brazil)'. The Favela Painting Project. Accessed 28 July 2020. https://favelapainting.com/PROJECTS.

Koolhaas, Jeroen, and Dre Urhahn. 'Favela Painting: Community art for social change'. The Favela Painting Project. Accessed 24 September 2020. https://favelapainting.com/.

Koolhaas, Jeroen, and Dre Urhahn. 'Praça Cantão, Rio de Janeiro 2010'. The Favela Painting Project. Accessed 25 November 2020. https://favelapainting.com/PRACA-CANTAO-FP.

Koolhaas, Jeroen, and Dre Urhahn. 'Santa Helena Project: Rio de Janeiro 2017-2018'. The Favela Painting Project. Accessed 26 December 2020. https://favelapainting.com/SANTA-HELENA-FP.

Linke, Uli. 'Fortress Europe: Globalization, militarization, and the policing of interior borderlands'. TOPIA: Canadian Journal of Cultural Studies 23-4 (2010): 100-20. [CrossRef]

Linke, Uli. 'Mobile imaginaries, portable signs: Global consumption and representations of slum life'. Tourism Geographies: An International Journal of Tourism Space, Place, and Environment 14, no. 2 (2012): 294-319. [CrossRef]

Linke, Uli. 'Racializing cities, naturalizing space: The seductive appeal of iconicities of dispossession'. Antipode: The Radical Journal of Geography 46, no. 5 (2014): 1222-39. [CrossRef]

Linke, Uli. 'ICONi@Cities: Global imaginaries of urban dispossession'. In Urban Imaginaries: A Routledge Companion, edited by Christoph Lindner and Miriam Meissner, 345-58. London: Routledge, 2019.

Lipsitz, George. 'Learning from New Orleans: The social warrant of hostile privatism and competitive consumer citizenship'. Cultural Anthropology 21, no. 3 (2006): 451-68. [CrossRef]

Lutz, Catherine A., and Jane L. Collins. Reading the National Geographic. Chicago: University of Chicago Press, 1993.

Mbembe, Achille. On the Postcolony. Berkeley: University of California Press, 2001.

Mbembe, Achille. Critique of Black Reason. Durham: Duke University Press, 2017.

Mendieta, Eduardo. 'Penalized spaces: The ghetto as prison and the prison as ghetto'. City 11, no. 3 (2007): 384-90. [CrossRef]

Mexal, Stephen J. 'Consuming cities'. In Eco-Man, edited by Mark C. Allister, 235-47. Charlottesville: University of Virginia Press, 2004. 
Mexal, Stephen J. 'The roots of "wilding"'. African American Review 46, no. 1 (2013): 101-15. [CrossRef] Neuwirth, Robert. Shadow Cities. New York: Routledge, 2006.

Nisbett, Melissa. 'Empowering the empowered? Slum tourism and the depoliticization of poverty'. Geoforum 85 (2017): 37-45. [CrossRef]

Peeples, Lynne. 'What the data say about police brutality and racial bias - and which reforms might work'. Nature, 19 June 2020. Accessed 28 June 2021. https://www.nature.com/articles/d41586-020-01846-z.

Perlman, Janet. Favela. New York: Oxford University Press, 2010.

Popova, Maria. 'Women are Heroes: A global portrait of strength in hardship by french guerilla artist-activist JR'. Brainpickings, 24 May 2012. Accessed 28 June 2021. https://www.brainpickings. org/2012/05/24/women-are-heroes-jr-book/.

Rahman, Fariah. 'The impact of Favela Painting'. PDX Scholar Studies 11 (2014). http://pdxscholar.library. pdx.edu/studies_srinq/11.

Rao, Vyjayanthi. 'Slum as theory: Mega-cities and urban models'. In The SAGE Handbook of Architectural Theory, edited by C. Greig Crysler, Stephen Cairns and Hilde Heynen, 671-86. London: SAGE Publications, 2012.

Remond-Tiedrez, Juliette. 'Women are Heroes by JR'. CreatingRights, 23 January 2019. Accessed 28 June 2021. https://creatingrights.com/2019/01/23/women-are-heroes-by-jr/.

Rolfes, Manfred. 'Poverty tourism: Theoretical reflections and empirical findings regarding an extraordinary form of tourism'. GeoJournal 75 (2010): 421-42. [CrossRef]

Ruby, Jay. 'Speaking for, speaking about, speaking with, or speaking alongside - An anthropological and documentary dilemma'. Visual Anthropology Review 7, no. 2 (1991): 50-67. [CrossRef]

Sennett, Richard. Flesh and Stone. New York: W.W. Norton, 1996.

Shohat, Ella. 'The struggle over representation'. In Late Imperial Culture, edited by Roman de la Campa, E. Ann Kaplan and Michael Sprinkler, 166-78. New York: Verso, 1995.

Spear, Joshua. 'Dionisio Gonzalez photography' Archive.joshspear.com, 11 December 2006. Accessed 28 June 2021. http://archive.joshspear.com/?s=gonzalez.

Spivak, Gayatri Chakravorty. The Post-Colonial Critic, edited by Sarah Harasym. New York: Routledge, 1990.

Steinberg, Stephen. 'The myth of concentrated poverty'. In The Integration Debate, edited by Chester Hartman and Gregory D. Squires, 213-27. New York: Routledge, 2010.

Stoler, Ann Laura. 'Imperial Debris: Reflections on ruins and ruination'. Cultural Anthropology 23, no. 2 (2008): 191-219. [CrossRef] .

Verilio, Paul. 'A topographical amnesia'. In The Visual Culture Reader, edited by Nicholas Mirzoeff, 108-22. London: Routledge, 1998.

Wacquant, Loïc. Urban Outcasts: A comparative sociology of advanced marginality. Cambridge, UK: Polity Press, 2008.

Washington Post Database. 'Police shootings database'. Washington Post, Accessed 26 June 2020. https: //www.washingtonpost.com/graphics/investigations/police-shootings-database/.

Williams, Caroline Randall. 'You want a Confederate monument, my body is a Confederate monument'. New York Times, 26 July 2020. Accessed 28 June 2021. https://www.nytimes.com/2020/06/26/ opinion/confederate-monuments-racism.html.

Wootson, Cleve R., Jr. "White Power" Video was a glimpse into Trump-era political discourse in "America's friendliest" retirement community'. Washington Post, 4 July 2020. Accessed 28 June 2021. https://www.washingtonpost.com/politics/white-power-video-was-a-glimpse-into-trumpera-political-discourse-in-americas-friendliest-retirement-community/2020/07/04/0ca405dc-bbc011ea-8cf5-9c1b8d7f84c6_story.html. 